\title{
The Role of School Management Teams in Cultivating Moral Purpose in Limpopo Secondary Schools
}

\author{
Matome L Ramalepe \\ Limpopo Department of Education/University of South Africa \\ tetelo4life@ymail.com
}

\section{Doi:10.5901/mjss.2015.v6n2p633}

\begin{abstract}
In the twenty-first century, South African education system embraced a new educational paradigm that utilised school management teams (SMTs) to lead schools. Reflecting on this movement, I explore the capacity of these management teams to cultivate moral purpose in Limpopo secondary schools. Using qualitative paradigm, I investigated the school managers' perceptions of moral purpose and how it can be nourished and translated into practice. Moral purpose was conceived as a relatively new concept to the majority of SMTs. Generally, those who were fully aware of their moral purpose understood it as a concept directed towards raising the level of learner achievement and improving school leadership. Such moral purpose is realised when the SMTs articulate the values of commitment, discipline and responsibility. The findings also enumerated a lack of parent involvement, learners' discipline, and teachers' lack of commitment to moral purpose as crucial factors that inhibit the sharing of moral purpose in schools.
\end{abstract}

Keywords: Moral purpose, shared moral purpose, teamwork

\section{Introduction and Background}

One of the notable upshots of democracy in South Africa was the introduction of the model of employing school management teams (SMTs) in schools. This move was informed by one of the strategic recommendations of The Task Team on Education Management Development which argued for a model in which school management is not located only in the formal position of the principal but it should be stretched over a range of people (DoE, 1996). This model encourages participative decision-making in which "... all members have the right to be heard, to have their views considered, to express feelings, to offer knowledge and information" (Owens, 2001:288). It simply facilitates that "decision-making processes, the crafting of a vision and mission of the school, the setting of the school ethos rest with the schools' stakeholders in schools" (DoE, 2002:2). The key elements of this notion are "participative 'democratic' management, collegiality, collaboration, schools as open and learning organisations, and, importantly, site-based management" (Van der Mescht, 2008:14). These key elements demonstrate the challenge facing members of the SMT to work democratically together and collaborate as they embrace the responsibility for the oversight of the functioning of the school. Therefore, the concept of team management is not only compatible with democratic principles, but also provides opportunities for school principals to redistribute power and responsibilities to others, and hence, easing pressure on themselves and improving their administrative efficiency. Sergiovanni (1984:13) concurs that "The burdens of leadership will be less if the leadership functions and roles are shared".

Ideally, shared leadership is an approach which describes a group or team of people working together towards an agreed objective (Spillane, Diamond, Sherer \& Coldren, 2005). This strongly suggests that there is the existence of the element of teamwork in shared leadership. Medwell (2009) understands that teamwork involves a gathering of a workgroup of individual experts with prescribed purposes, they communicate, cooperate, and make decisions together, and have the knowledge and ability to work together to make work plans to accomplish goals. This definition highlights that, within the shared leadership approach teams should be established and allowed to own goals. Therefore, a goal of enhancing leadership and learner achievement can only be realised if the SMTs perceive that leadership can be effective when it is shared or distributed. They ought to acknowledge that the complexity of school leadership in the twenty first century requires greater collaboration as a means to an effective distribution of tasks and responsibilities (Cannon, Delaney \& Host, 2007). The factors that attract organisations to opt for shared leadership are that the approach actually works in practice and it builds commitment among those involved (Duignan \& Bezzina, 2006). In addition, the value of this paradigm is that staff empowered to collaborate can create an excellence institution, and empowerment through mutual 
commitment enables staff to achieve more together than they could do as individuals (Wallace (2001). Schools embracing the shared leadership approach are more likely to enjoy high performance levels of teachers and learners than those that are still opting for the one-hero model of leadership.

While articulating the merits of greater collaboration and distribution of leadership, Cole (2006) and Williams (2011) identified a range of factors that challenge the efficacy of shared and/or collaborated leadership in schools. These factors include: the authoritarian ethos of school principals, cultural and gender biases, teams meeting infrequently, and teachers' reluctance to participate in leadership roles. In support of the above are two South African studies, one by Bush and Glover (2008) and the other by Grant (2006) which found that many SMTs in South Africa do not operate effectively, either because they rarely meet or because of the practice where 'top-down' decisions are still the norm. Bush and Glover (2008) further report that fractured interpersonal relationships often make effective team work impossible. Therefore, the starting point in enhancing team effectiveness is to have school principals who are able to create a productive environment by diagnosing these challenges and providing remedy.

Notwithstanding the abovementioned challenges, the shared leadership perspective practiced by teams can be seen as an important vehicle by means of which moral purpose is given expression (Bezzina, 2007, 2010). He argues that shared leadership is a primary way of enhancing the pursuit of and commitment to moral purpose and its underlying goal. What is the overarching goal of moral purpose? Fullan (2002:4) states that "In addition to the direct goal of making a difference in the lives of students, moral purpose plays a large role in transforming and sustaining system" Therefore, the central goal of moral purpose is to transform the learning of all learners and to raise their levels of achievement. Similarly, Barber and Fullan (2005) argues that the central moral purpose consists of constantly improving learner achievement and ensuring that achievement gaps between higher and lower performing learners or schools are narrowed. In addition, Fullan (2003) states that moral purpose also involves treating people with commanding respect. This implies that in order to achieve the crucial goal of moral purpose, the SMTs need to create an atmosphere where teachers, learners and parents treat each other with respect. Treating people with respect involves controlling any impulses that adversely affect other people in the school. The element of respect points to the importance of moral leadership in the cultivation of moral purpose. Moral leadership is premised on the assumption that the critical focus of leadership ought to be on the values, beliefs and ethics of the leaders themselves (Bush, 2007). For example, if integrity is the leader's core value then this will come through in his or her leadership and the way he or she interacts with others. Integrity is particularly associated in people's minds with the qualities of honesty and consistency (University of Pretoria, 2010:7). Therefore, leaders acting with integrity are straightforward with people so that they know where they stand, and they apply the same value system in all situations, whether in private or public. However, the University of South Africa Study Guide (2007) argues that because of the ethical complexity surrounding us it is not always easy to lead with integrity.

\section{Theoretical Framework}

This theoretical framework encapsulates two major themes which are drawn from two significant frameworks developed by international researchers to guide and support leadership and moral purpose in schools (Fullan, 1993, 2001, 2002, Bezzina, 2007, 2008, 2010). The first theme represents the central foci of this study, namely, moral purpose and how it enhances relationship building. The second theme reflects the concept of team management as a core aspect of shared leadership, which is, in turn, the fundamental component facilitating moral purpose. In his leadership framework, Fullan $(1993,2001)$ perceives moral purpose as one of the core components of leadership. Implicit within this framework, the concept of moral purpose is seen as inculcating in leaders a sense of making a positive difference in the lives of learners, teachers, parents and society as a whole. These leaders have a "commitment to improving standards, no matter what, and ensuring that the gap between students is narrowed when it comes to achievement" (DoE, 2008b:27-28). This moral purpose would also permeate how SMTs treat others whether they are learners, teachers, or parents (Bezzina, 2007, 2010).

Therefore, moral purpose is the basis for relationship building (Fullan, 1993). SMTs guided by moral purpose grounded on the aspect of respect are consummate relationship builders in their schools. They constantly foster purposeful interactions and problem solving in their schools. Collins (2011) argues that in great organisations the leader gets relationships right first and then deals with [moral] purpose. Fullan (2011) concurs that if you want to challenge someone to do better you had better build a relationship first. This reinforces the importance of moral purpose to establish collaboration in teams. Closely connected to this theme is the challenge explored in this study, the degree to which shared leadership enhances the sharing of moral purpose. There is a need for this moral purpose to be shared and its purpose should be grounded in a shared commitment to explicit values (Andrews \& Lewis, 2004). It is within the context of shared leadership that moral purpose is explicit and shared (Bezzina, 2008). This means that moral purpose can be 
shared when leadership practices are not limited to those in formal positions.

\section{Research Problem and Questions}

In Limpopo Province, a pressing need has emerged over the past four years to improve school management and learner achievement (LDoE, 2011). Therefore, exploring the concept of moral purpose in this context serves as a framework by which SMTs can ensure commitment to and translation into action of the goals of improving these two aspects in schools. This research reinforces the importance of moral purpose in teams, but also seeks to give explicit attention to how managers understand moral purpose and how conscious engagement with it can bring about change in schools. Flowing from the above, this study was guided by the following primary question: How can school management teams cultivate moral purpose in secondary schools? Four sub-questions for this study were:

- What do the members of school management teams identify as moral purpose?

- How can school management teams share moral purpose?

- Which factors inhibit school management teams to enact the moral purpose of the school?

- How can school management teams overcome factors inhibiting moral purpose?

\section{Methodology}

The research was focused within the interpretive or constructivist paradigm where as a qualitative researcher "I stressed the socially constructed nature of reality, the intimate relationship between the researcher and what is studied, and the situational constraints that shape inquiry" (Denzin \& Licoln, 2000:19). This approach focuses on what the participants view as reality within their context and reality is then portrayed in the form of individual reality. The case study design which involved six secondary schools was used. I chose case study approach for this research for several reasons. Firstly, there was limited or no research done so far in South Africa on the enactment of moral purpose in schools by school management teams. Therefore, given the limited or no research done in this area it would have been difficult to construct a data collection approach based on existing evidence. Secondly, the research questions focus around building theory on the process of cultivating moral purpose in schools. This means that the research is trying to establish how and why school managers enact moral purpose. Such how and why questions are also considered to be particularly suited to a case study approach (Yin, 2003). The six schools were drawn as case studies simply because "they just happened to be conveniently situated, spatially or administratively, near to where the researcher is conducting the data collection" and their "availability [willingness to participate], accessibility and theoretical interest" (Schwandt, 1997, 140-141, Marshall \& Rossman, 2007:7).

Thus, five schools were based in Mopani district as I am located in this area and currently working in this district, and this gave me easy access to schools. One school was chosen from the Capricorn district because of its convenient geographical proximity as approximately two hours is required to drive from my hometown to where this school is based. The participants within these six case studies (secondary schools) consisted of principals, deputy principals and heads of department. These participants were selected for interviews by means of purposive sampling. This technique was preferred because in purposive sampling I was able to select particular participants [principals, deputy principals and heads of department] from the population who were representative of the larger group of Limpopo school managers or they were informative about the topic of interest (McMillan \& Schumacher, 1993, 2006). Data collection for this research was undertaken through the use of three separate yet complementary instruments: semi-structured interviews, document collection and analysis, and observations. The major focus was the use of individual semi-structured interviews with all members of the SMTs. Data obtained through the interviews was supplemented by material from key documents from the research contexts. These documents included Schools' mission statements, strategic plans, minute books, annual reports and school improvement plans as well as guiding documents from systemic authorities. I also received hard evidence of new ideas on the cultivation of moral purpose in schools by conducting structured observations.

To ensure meticulous recording of data, I used a tape recorder with the permission of the participants to record the interview data (Maree, 2007:89). Wanting to situate myself in the data and the intent of the interviewees once the primary data collection phase had been completed, I transcribed the interviews manually. Data was examined and organised according to the four research questions. During this research all reasonable steps to maintain the confidentiality and anonymity of the participants were taken. These steps revolved around dual responsibility described by McMillan and Schumacher (1993:399): firstly, "the protection of the participant's confidence from other actors in the setting whose private information might enable them to identify them and, secondly, the protection of informants from the general 
reading public". In line with this, I did not reveal information about the attitudes, motivations or behaviour that a participant would rather not have revealed (Thompson, 2008). The real names of schools and participants were changed to ensure anonymity and confidentiality (e.g. Apple High School: Principal).

\section{Research Findings and Discussions}

From the data analysis several themes emerged and were categorised within the four research questions. However, given the limited scope of this paper, only four themes are explored.

\subsection{Perceptions of moral purpose}

The interview participants were challenged to identify and explore moral purpose underlying educational leadership approaches that they take to generate positive learning outcomes such as examination results. Overall, the responses generated through follow-ups and probing revealed that the concept of moral purpose was the least familiar to research participants. Nonetheless, the general perception was that moral purpose involves a conscious improvement of learners' lives by producing excellent learning outcomes. Grape High School Head of Department B stated that "... the moral purpose of the school is to put the results higher and higher and higher until we don't have any failure in our school". Apple High School's Academic Tutor called it the "moral goal of achievement", which he said it was fulfilled in their school when "... the whole SMT plays a role via monitoring classes, checking the work that has been done, all the work that need to be done, and providing guidance". Moral purpose as a "moral goal of achievement" requires that school managers explicitly position themselves at the nexus of improving learning and closing the gap between top achievers and lower achievers in schools. This resonates with Barber and Fullan's (2005:3) argument that "The central moral purpose consists of constantly improving student achievement and ensuring that achievement gaps, whenever they exist are narrowed".

In line with the foregoing, Orange High School Deputy Principal described their school's moral purpose as "... to achieve better matric results." There is a sense that she understands moral purpose in relation to grade twelve examination results and illustrated that profound commitment to this moral purpose has transformed the school's academic results when it comes to grade twelve results. Accordingly, Peach Secondary School Head of Department A perceived that "... moral purpose is the vision of our school." A review of the Vision Statement document disclosed that the vision of Peach Secondary School is a vision for academic achievement. This is congruent with Cuttance et al.'s (2003) description of moral purpose as whole school vision and goals that becomes a "broad directional vision" (Fullan, 2009:109). The participants' perception highlights the central role of the school vision focusing on academic success in producing improvements in learner achievement. Therefore, "whole-school vision for the academic success for all learners" is a moral purpose that underscores the need to have the school vision focused on the achievement of all learners regardless of background. The moral purpose viewed in this way challenges all stakeholders to make a concerted effort to achieve it. The important role of school leaders is to facilitate the participatory process of conceptualising and negotiating the vision.

\subsection{Key values of moral purpose}

The participants in this research believe that moral purpose can be expressed in terms of three fundamental values which are imperative in enhancing academic achievement. Verily, without values to guide and direct our lives, we are like ships without rudders that are flung to and fro on the capricious ocean of existence (University of Pretoria, 2010). First, Apple High School's Academic Tutor believes that the key expression of moral purpose in their school is "Commitment, total commitment from our staff ..." Peach Secondary School Acting Principal added that commitment and dedication should be embraced by all managers, teachers and learners as they engage in various tasks and activities. She said "The key expressions of moral purpose in Peach Secondary School are commitment and dedication of managers, learners and educators." Accordingly, the Banana High School Principal stated that teachers should understand that teaching learners is their moral responsibility and "... the key responsibility of any teacher at school is to be in class on time and do what he or she is expected of or seen to be doing." This implies that the evidence of teachers' commitment and responsibility in the classroom includes nothing less than effective teaching, assessing, and giving constant feedback to learners. There was also a great recognition that being a leader starts with a conscious decision to commit oneself to the task of leading (University of Pretoria, 2010). Thus, Day (2008) states that committed and passionate school leaders exhibit a clear enduring set of values and ideologies which inform practice regardless of social context and the active rejection of a 
minimalist approach to leadership (to just doing the job). This means that committed school leaders have a clear set of personal values that guide them and keeps them focused on their work, regardless of what they have to cope with on a daily basis.

Interestingly, the research found that the school managers in effective schools achieve the central goal of moral purpose by showing commitment to aspects of instructional leadership, namely, monitoring, support and modelling. Generally, the participants' remarks illustrate the seriousness of the role the SMT plays to support teaching and learning. The essence of this reflection that "SMT's commitment in the areas of monitoring, modeling and supporting is a key to improvement of learner achievement" is reflected in the notion of instructional leadership reinforced by Southworth (2002, 2004). For example, Banana Secondary School Principal claimed that he is able to improve learner achievement because he model good classroom practices. He said "I lead by example. I also teach grade twelve." The Apple High School Head of Department pointed at the power of modelling and stated, "... whatever you can't do, you can't expect others to do." He added that "Expectation should be led by feasibility, we can do this, and I have tested that through my own experiences in the field. And so if we end up having to demand anything from other teachers, this is the way." If SMTs expect to see teachers demonstrating the values of commitment and responsibility in their teaching practices they should be the first to manifest these practices in the way they teach and lead. Thus, the Apple High School Principal states:

Teachers must see me leading by example. So they have realised that principal is a person who go extra mile, he will come to school at half past six, go to the media centre, get learners there, sit with them, conduct morning studies, start with us in the staff briefing.

Amidst the interview data, several other values were accepted by participants interviewed as expressing moral purpose. The first was the value of discipline with regard to which the Banana Secondary School Principal remarked "We cannot have good performance in an environment which is not discipline driven." It is clear from the above comments that school managers view the creation and maintenance of discipline structures in their schools as the basis for the enhancement of learner achievement. Sound learner discipline increases learner performance because it reduces late coming and absenteeism. On the reduction of late coming the Orange High School Head of Department B explained that "Here at our school we don't know anything like late coming. We start early in the morning, at seven o'clock learners are all here, they are even used to that." It is therefore the task of school managers at all levels to promote self-discipline in the school environment utilising the view of responsibility associated with the task allocated to them. Discipline helps SMTs, teachers and learners to maintain focus on the set targets by controlling both internal and external factors that may potentially derail them from achieving standards set by the school. In order to attain the high standards for learner achievement through respect for targets, commitment to tasks and taking responsibility, SMT, teachers and learners should maintain a high standard of discipline in everything they do in the school. To me, therefore, Collins and Hansen's (2011) 'fanatic discipline' and Fullan's (2011) 'focus on implementation' highlight the important role played by the value of discipline in achieving the cultivation of moral purpose in schools. To achieve school improvement, the Orange High School Head of Department A stated that "We need discipline from our staff, we start on top, discipline from a staff, being at school, attend classes, be on time, be prepared." In a disciplined school environment teachers attend school and classes on time and prepare for their lessons adequately, and all these practices are necessities for the enhancement of moral purpose.

\subsection{Teamwork and the central goal of moral purpose}

It became apparent in the above sections that improving learner achievement, particularly the grade twelve results, is a central goal of moral purpose which is achieved by SMTs that are laden with underlying values such as commitment, responsibility and discipline. However, participants have strong view that the goal of raising achievement levels for all learners does not happen by accident but requires the establishment of teamwork in schools:

Achievement of learners starts with teamwork. Everything starts with teamwork ... whenever there is something, the way we exchange, the way in which we assist each other, we work as a team. And then even the teachers out there when they see us they see this team spirit. It is difficult nowadays to get people to operate as a team. But if you come to Apple High School, there are different because these people work as a team, they understand each other. We are all focused; we know what we want, and where we are heading to. The reason why the school is so successful in terms of grade twelve results is because of teamwork, of sharing of ideas and consultation, not undermining each other (Apple High School Principal). 
Banana Secondary School Principal also espoused on team notion as a key approach for enhancing moral purpose: "Under normal circumstances the school is doing well because we work as a team ... that is what put our learners on the map." The perceptions of the two principals above are that by espousing the notion of teamwork not only as democratically viable but also as morally acceptable has helped their schools to improve learner achievement. Overall, the participants understand the concept of teamwork as not just a group of people working together but as people unified around a compelling moral purpose, sharing responsibilities and cooperating to improve learner achievement. The notion of 'sharing' allows the SMTs to have a wider range of ideas to solve problems than a single manager. Accordingly, Darren (2010:71) identified "a willingness by members to share, even to sacrifice" as a key feature marking the effectiveness of the SMTs. However, sharing is only possible in teams that are "having communication, having cooperation, and knowledge and ability to work together in making work plans to accomplish the goal" (Mendwell, 2009:320). That is, it would be impossible for members of the SMTs to be willing to share in an environment in which principals have restricted channels of communication and members have no skills in collaboration. It is therefore important to equip SMT members with good communication skills and develop their understanding of team dynamics such as respect and patience. Another key dimension of teamwork that emerged in my research is that teamwork consists of a collection of individuals who are not only interdependent in their tasks but "who [also] see themselves and who are seen by others as an intact social entity ... who manage their relationship across organisational boundaries" (Cohen \& Bailey, 2007:106).

However, my observations of the sampled schools proved that the majority of SMT members might have talked about teamwork without necessarily actualising it in their schools. Plain evidence of this was the lack of SMT and staff meetings which are instrumental in ensuring team communication and cohesion, both of which are key elements of teamwork. Analysis of the minutes of SMTs' previous meetings also supported this evidence as there were no recent SMT meetings held in four schools. Two of these schools are underperforming in the grade twelve examinations. Another challenge facing school principals when undertaking the duty to promote teamwork is the defiant attitude of some team members who are not positive and cooperative. The Banana High School Principal states that "... you always have a black sheep in the kraal." He reports that "We have some who are doing other things that are not in line with our team vision and moral purpose." Mostly, an example of such attitudes is lack of commitment evident with respect to the decisions made by the team (Cole, 2006).

The participants' responses illustrated that their notion of teamwork overlaps with participative decision-making:

Each and every time whenever there is a decision to make, be it about achievement of learners or school programme, as long as I feel like I cannot do this alone, I call my colleagues and teachers and say guys here is the issue, let us sit around the table and discuss (Apple High School Principal).

This remarks show that the inclusive decision-making process that is a central focus of all individuals in the school can produce improvement in learner achievement. This means that in the context of my research, the participative notion not only bonds staff together around a decision about learner achievement, but also lessens leadership pressure on the school principal. The emphasis on participative decision-making is based on the assumptions that participation will increase school effectiveness and that in the context of site-based management, leadership is potentially available to any legitimate stakeholder (Leithwood, Jantzi \& Steinbach, 1999). Owens (2001:288) argues that "In participative decisionmaking, all members have the right to be heard, to have their views considered, to express feelings, to offer knowledge and information". The data show that principals also believe strongly in broad participation to include learners and parents: "Now we are trying to involve parents and even the learners themselves in whatever decision we take they are involved" (Orange High School Head of Department A).

\subsection{Threats and challenges inhibiting moral purpose}

While acknowledging the need to take increased responsibility to articulate and share moral purpose, members of the SMTs noted that the increasing complexity of the South African education system is posing a number of inhibiting threats and challenges. All participants, irrespective of whether or not moral purpose and leadership are widely shared within their schools, felt that most inhibitors are associated with various role players in the school. Firstly, there was an overwhelming acknowledgement that learner discipline is a huge challenge experienced by SMTs in the everyday cultivation of moral purpose. Orange High School Head of Department B accentuated that "... you find that even though we try our best as a school, you will find that a few learners sometimes do deviate from what is our moral purpose." Although the school is experiencing minimal cases of learner misconduct, the Apple High School Deputy Principal A admitted that there is "... a small group of learners who we seem not to be getting right with them." Her colleague, Apple 
High School Head of Department echoed this response reporting that "Apart from that maybe you might find that we also have different children that are beyond repair when it comes to issues of discipline." The following response highlights succinctly the frustration of having to deal with a small group of ill-disciplined learners:

\begin{abstract}
And you try this and they just want to get the worst out of everybody ... Daring attitude where a child shows you can't take me anywhere, you can't do anything and everything, and you know we don't even use corporal punishment. You reach a point where you feel much more helpless and so you can't influence that child. And this affects us in the sense that when you set a goal and say we need hundred percent as a school, then you have that child who is sitting there and hijacking your dream (Grape High School Head of Department B).
\end{abstract}

The most serious factor encouraging disciplinary problems in learners was abuse of intoxicating substances such as drugs and alcohol. The Peach Secondary School Acting Deputy Principal affirmed that learners' disciplinary problems manifest themselves "... either because those learners are on drugs or are abusing alcohol, we have such learners." Grape High School Head of Department A added that "Most of the learners are using glue and dagga and on Monday they come here drunk from the weekend and some come to school late." My observation at Grape High School bore out this tendency of learners to come late to school, especially on Mondays. During my visit to the school on one particular Monday, I observed many learners locked outside the school gates because they were late. Discipline is important because in order to raise the level of learner achievement for all learners in the school, learners must be:

... in class on time and do what they are expected to be doing. They should be in class, they should be taught, and they should also adhere to the teacher's instructions to make sure there is effective teaching and learning" (Apple High School Deputy Principal A).

Therefore, moral purpose thrives in an environment characterised by learners who respect instructional time and willingly cooperate with teachers in the classroom. But to establish classrooms where teachers and learners collaborate in order to ensure that the central goal of moral purpose is achieved is not easy because "... learners who abuse these intoxicating substances become unruly in classrooms" (Peach High School Acting Principal). She complained about this and says that "sometimes we don't know what to do about them as a school." According to the Apple High School Deputy Principal A, disciplinary problems such as unruly classroom behaviour may occur because "... those learners come from family backgrounds with social issues that need to be addressed." One social factor that was raised by three participants attached to schools in rural areas was that of learners heading families in the absence of their parents either because they were deceased or working in Gauteng. The Peach High School Acting Principal explained that this factor has an impact on learner achievement because "... as a result the school experiences a high degree of absenteeism." It emerged that this high rate of absenteeism jeopardises efforts taken by SMTs to cultivate the moral purpose of improving achievement of all learners in schools. In addition to learner absenteeism, the Banana Secondary School Principal states that"... you find that these learners do not even write homeworks." Confirming these findings is The Western Cape Education Department's manual titled A Practical Guide to Understanding and Managing Learner Behaviour that espouses:

Learner behaviour problems have, for years, been a major concern for educators, administrators and parents. More than ever before, educators are faced with critical problems in their classroom, and are confronted with unacceptable learner behaviour and threatening situation (WCDOE, 2007).

The dilemma for an overwhelming majority of SMT members is the challenge of not being able to persuade parents to support them in addressing the disciplinary issues of learners in their schools. Thus, it was apparent that parent involvement and participation are critical in the cultivation of moral purpose in schools. The participants held a strong view that it would be difficult, almost impossible, to enhance learner achievement without the involvement of parents. According to Squelch and Lemmer (1994), parent involvement is the participation of parents in a wide range of schoolbased and home-based activities to improve their children's education. They further claim that the benefits of parent involvement include improved school performance, reduced dropout rates, a decrease in delinquency, and a more positive attitude towards the school. Although experiencing few instances of parents not participating in the affairs of the school, the Apple High School Deputy Principal A confirmed:

And of that sample I have spoken to you about, we don't get cooperation because either the parents are very protective or they are busy, their schedules are so busy, they don't have time to come to school. And you feel like you are stuck with the soul and you don't know what to do with the child. 
Therefore, lack of parent involvement and participation is equally a detrimental factor which is exacerbating the issue of learner discipline in schools. Orange High School Head of Department B asserted that "You find that if some of the learners when they are ill-disciplined, when we call parents, some parents do not come to school." Even if the parents do come to school, they display a negative attitude and protect their children. Grape High School Head of Department B substantiated that "... when the parent tries to intervene, [he/she] will intervene protecting the child." In a worst case scenario, Peach Secondary School Head of Department A stated that some parents instead of supporting the teachers, "They are looking at alternative way, a legal way on how to show or prove to the teacher that you did not follow the procedures ... This kind of attitude gives learners the impression that they are untouchable." He stated that some of these kids will go to the extent of threatening the teacher that "I will tell my father to sue you." This research further validated the findings of Bush et al. (2008) who identified 'disinterested and/or illiterate parents and/or dysfunctional families as major factor(s) that inhibit South African principals to overcome the problems from the schools' contexts and to build on the supportive factors. Illiteracy, perhaps due to the legacy of apartheid education, appeared to be a critical factor hampering parents' involvement because the majority of undereducated or uneducated parents become totally disinterested in their children's education.

Furthermore, evidence in this report creates an unsolicited image that teachers' behaviours such as their laziness to execute duties assigned to them hamper the sharing of moral purpose in schools. Commenting directly on factors inherent in teachers, Apple High School Head of Department highlighted personal clashes that might arise because of what he calls the "human factor", which means that even if teachers "... were born on the same day, sharing the same mom, there will always be different people. So that one will be the point of departure that you will see one eye to eye on many issues but not hundred percent." In addition, absenteeism of staff emerged amidst the data as another challenge that inhibited moral purpose. The Banana Secondary School Principal explained that "The challenge that I have experienced at this school from various departments is absenteeism." He added that "... like it is hardly a month without having people being absent, maybe because of personal issues." According to him, a more deeply rooted cause of absenteeism may be that "There are some who are ill; I have got about three who have chronics..." Lack of commitment in teachers also surfaced as an issue that is hampering the sharing of moral purpose. Peach High School Head of Department B asserted that "... some educators are not committed to their work." In the same vein, Orange High School Head of Department B stated:

Because sometimes when you delegate people keep on postponing. You know, sometimes a person will say I will do it and when you inquire the following day, he/she will say the next day. That is why I am saying such factors like laziness are the ones that are hampering the smooth running of the school.

Notwithstanding the universal acceptance of the importance of sharing moral purpose, the reality is that a group of experienced and passionate professionals will occasionally struggle to agree on every issue. An overwhelming majority of SMTs concur that members of teams do have clashes but they quickly reach consensus through robust debates for the sake of the learners. Therefore, most members of the SMTs from various schools could not remember any instance where the sharing of moral purpose was hampered by the behaviour of one of the members of their SMTs. Evident in the data is that despite being confronted by numerous inhibiting challenges, SMTs believe in the notion that no challenge is stronger than teamwork.

\section{Conclusions}

Although the concept of moral purpose appeared to be essentially unfamiliar to the majority of the members of SMTs, the responses generated confirmed some of the views discussed in the literature regarding the meaning and significance of moral purpose. The school managers highlighted that moral purpose should consist of constantly improving learner achievement and respecting all teachers and learners in the school. Generally, moral purpose is perceived as a "compelling moral imperative" or "moral goal of achievement" directed towards raising the achievement levels of all learners in the school. This whole-school vision for academic achievement is achieved by ensuring that the achievement gap between higher and lower performing learners is narrowed. To realise this moral purpose, members of the school management teams highlighted that they have to be imbued with and express three underlying values, namely, commitment, responsibility and discipline. The expression of moral purpose through these key values implicitly suggests that SMTs of higher performing schools share these values to create school cultures with transformed teaching and learning processes. They show commitment to activities associated with instructional programmes and activities designed to achieve higher standards. The main activities they perform are monitoring, modeling good classroom practices and 
providing support to the teachers. They are also accountable for the learning outcomes of their learners and are able to maintain a disciplined approach to work.

Generally, the research draws out the picture that teamwork is an overarching educational notion that provides an opportunity for schools to cultivate moral purpose. The school managers' responses indicate several positive attributes of teamwork and the primary of these seem to be the notion of participative decision-making and sharing. On the notion of participative decision-making, the members of SMTs claimed that their schools have moved from 'one-man' authoritarian leadership and 'unilateralist's decision-making' to collective decision-making. The general view is that participation and involvement of people in the decision-making process do not only endorse the democratic nature of leadership but also provide the opportunity for people to adjust their behaviours in order to support the schools' agenda to improve learner achievement. On the aspect of sharing, the SMT members reinforced the benefits offered through the utilisation of diversity of skills and knowledge or opinions within the team. The healthy, constructive and respectful debates in meetings were identified as the hallmarks of effective sharing of diverse opinions and complementary skills. Effective sharing was also seen as a means by which effective school shared their moral purpose.

However, undermining the sharing of moral purpose are sets of tensions and challenges which make the actual sharing of the moral purpose potentially problematic. Learner discipline arose as a major threat, since attainment of higher achievement standards requires an atmosphere that is discipline-girded with no disruptive behaviours of learners. The challenge of learner discipline is exacerbated by lack of parent involvement and participation arising from dual factors: on the one hand, parents are illiterate and, on the other hand, they are not showing interest in the education of their children. Interpersonal problems or differences within the SMT emerged as another threat, with the diversity of personalities and attitude being detrimental to the process of sharing moral purpose. These may include personal agendas of individual members of the SMT which may result in potentially harmful conflicts amongst them, thereby working against the sharing of moral purpose. Significantly, lack of commitment or laziness on the part of the teaching staff emerged as another challenge that was seen to lead to the postponement of executing duties delegated to them by the SMT. Consequently; SMTs view laziness of teachers as a factor that defies their ambitions to achieve higher achievement standards for learners.

\section{References}

Barber, M. \& Fullan, M. (2005). Tri-level development: It's the system.

Bezzina, M. (2007). Moral purpose and shared leadership: The Leaders Transforming Learning and Learners pilot study. Paper presented at the ACER Conference: The Leadership Challenge, Improving Learning in Schools. Melbourne.

Bezzina, M. (2008). We do make a difference: Shared moral purpose and shared leadership in the pursuit of learning. Leading and Managing, 14(1), 38-59.

Bezzina, M. (2008). We do make a difference: Shared moral purpose and shared leadership in the pursuit of learning. Leading and Managing, 14(1), 38-59.

Bezzina, M. (2010). Paying attention to moral purpose in catholic schools: lessons from Leaders Transforming Learning and Learners. Paper submitted to $5^{\text {th }}$ International Conference on Catholic Educational Leadership.

Bush, T. \& Glover, D. (2008). Managing teaching and learning: A concept paper, Johannesburg: Matthew Goniwe School of Leadership and Governance.

Bush, T. (2007). Educational leadership and management: Theory, policy, and practice. South African Journal of Education, 27(3), 391406.

Bush, T., Joubert, R., Kiggundu, E. \& Van Rooyen, J. (2008). Leading and managing literacy and numeracy. Johannesburg: The Zenex Foundation.

Cannon, H.M., Delaney, V. \& Host, S. (2007). Redesigning the principalship. Paper presented at the Fourth International Conference on Catholic Educational Leadership Sofitel Wentworth, Sydney.

Cohen, L. \& Bailey, D.E. (2007). What makes teams work? Group effectiveness research from shop floor to executive suite. Journal of Management, 23 (3), $239-290$.

Cole, P. (2006). The leadership team charter: A strategy for strengthening school leadership. The Australian Educational Leader, 28(2), 10-12.

Collins, J. \& Hansen, M. (2011). Great by choice. New York: HarperCollins.

Cuttance, P., Stokes, S., McGuiness, K., Capponi, N., Corneille, K., Jones, T. \& Umoh, C. (2003).

The National Quality Schooling Framework: An interactive professional learning network for schools. Melbourn: University Press.

Darren, J.E. (2010). An exploration of the role of senior leadership teams in enhancing the mission integrity of selected Catholic schools in the Mercy tradition. Doctoral thesis, Australian Catholic University.

Day, C. (2008). Successful leadership: An intelligent passion in passionate leadership in education. London: Sage.

Denzin, N.K. \& Lincoln, Y.S. (2000). Handbook of qualitative research (2nd Ed.). Thousand Oaks, Calif: Sage.

Department of Education (1996). Changing management to manage change in education. Report of the Task Team on Education 
Management Development. Pretoria: Government Printers.

Department of Education (1996b). South African Schools Act (SASA). Pretoria: Government Printers.

Department of Education (2002). The building of capacity of 1500 schools to enable them to be granted section 21 status in 2003. Pretoria: The Department of Education.

Duignan, P. \& Bezzina, M. (2006). Distributed Leadership: The Theory and the Practice. Paper presented at the Commonwealth Council for Educational Administration Conference, Lefkosia, Cyprus.

Fullan, M. (2002). Principals as Leaders in a Culture of Change. Paper prepared for Educational Leadership, Special Issue, May 2002. (Accessed on 22 August 2011 from http://www.michaelfullan.ca/).

Fullan, M. (2003). The moral Imperative of School Leadership. Thousand Oaks: Corwin Press.

Fullan, M. (2009). Large-scale Reform Comes of Age. Journal of Educational Change, 10, 101-103.

Fullan, M. (2011). The Moral Imperative Realized. Thousand Oaks: Corwin, and the Ontario Principals' Council.

Grant, C. (2006). Emerging Voices on Teacher Leadership. Some South African Views. Educational Management Administration and Leadership, 34(4), 511-532., Aston University Lakeside Conference Centre Birmingham, England.

Leithwood, K., Jantzi, D. \& Steinback, R. 1999. Changing Leadership for Changing Times. Buckingham: Open University Press.

Limpopo Department of Education (LDoE) (2011). Turn-Around Strategy to improve education in

Limpopo: Basic Education \& Further Education and Training System. (Accessed on 10 April 2011 from http://www.limpopodepartment ofeducation.org.za).

MacMillan, J.H. \& Schumacher, S. (1993). Research in education - a conceptual introduction (3rd Ed). New York: HarperCollins College Publishers.

MacMillan, J.H. \& Schumacher, S. (2006). Research in education - Evidence-based Inquiry (6 $6^{\text {th }}$ Ed.). International Edition. Boston: Pearson Education Inc. Pergamous Press.

Maree, K. (Ed.) (2007). First steps in research. Van Schaik: Pretoria.

Marshall, C. \& Rossman, B. (2006). Designing qualitative research. Thousand Oaks: Sage.

Mendwell, J. (2009). Developing a model of Teacher - Team Building at secondary schools in Thailand (5th Ed.). New York: Longman.

Owens, R.G. (2001). Organizational behaviour in education: Instructional leadership and school reform ( $7^{\text {th }}$ Ed.). Boston, Mass: Allyn and Bacon.

Schwandt, T.A. (1997). Qualitative inquiry: A dictionary of terms. Thousand Oaks: Sage.

Sergiovanni, T.J. (1984). Leadership and Excellence in Schooling. Educational Leadership, 41(3), 4-13.

Smit, P.J. \& Cronjé, G.J. (1992). Management principles: A contemporary South African edition. Kenwyn: Juta.

Southworth, G. (2002). Instructional leadership in schools: reflections and empirical evidence. School Leadership and Management, 22(1), 73-92.

Southworth, G. (2004). Learning-Centred Leadership. In Davies, B. (Ed.), The Essentials of School Leadership. London: Paul Chapman.

Spillane, J.P., Diamond, J.B., Sherer, J.Z. \& Coldren, A.F. (2005). Distributing Leadership. In Coles, B.J. \& Southworth, G. (Eds.). Developing Leadership: Creating the schools of tomorrow (37-49). Maidenhead, UK: Open University Press.

Squelch, J. \& Lemmer, E. (1994). Eight keys to effective school management in South Africa. Halfway House: Southern.

University of Pretoria (2010). Management and Leadership in Education. Study Guide for LVO 721.Pretoria: University of Pretoria.

University of South Africa (UNISA) (2007). Managing the schools as organisation. Study Guide for HBEDMS-V. Pretoria: UNISA.

Van der Mescht, H. (2008). Educational leadership and management - some thoughts from the field. Journal of Education, 44, 7-24.

Wallace, M. (2001). Sharing Leadership of Schools through Teamwork. Educational Management \& Administration, 29(2): 153-167.

Western Cape Education Department (WCDoE). (2007). Learner Discipline and School Management. A Practical guide to understanding and managing learner behaviour within the school context. (Accessed on 20 August 2009) from http://www.westerncape educationdepartment.gov.za).

Williams, C.G. (2011). Distributed leadership in South African schools: possibilities and constraints. South African Journal of Education, 31: $190-200$.

Yin, R.K. (2003). Case Study Research: Design and Methods. Thousand Oaks: Sage. 